\title{
Association between Serum Ferritin and Iron Parameters with Preeclampsia and its Association with Perinatal Outcome
}

\author{
Lipika Ghosh ', Rowshan Afrooz ${ }^{2}$, Saleha Begum Chowdhury ${ }^{3}$, Osman Gani ${ }^{4}$, Rokhshana Khatun ${ }^{5}$,
}

\begin{abstract}
Background \& objective: To see the relationship between preeclampsia and iron parameters (serum iron, serum ferritin and total iron binding capacity).

Methods: The present case-control study was carried out in the Department of Obstetrics \& Gynaecology, Dhaka Medical College Hospital (DMCH), Dhaka in collaboration with the Department of Biochemistry, BSMMU, Dhaka over a period of 1 year from July 2012 to June 2013 Pregnant women with preeclampsia admitted in the above-mentioned hospital were considered as case, while the pregnant women without preeclampsia were included as control. A total of 60 women-31 cases and 29 controls were purposively included in the study. The exposure variables were serum ferritin, serum iron and total iron binding capacity (TIBC), while the outcome variable was preeclampsia. The serum iron level $>100 \mu \mathrm{g} / \mathrm{L}$ was considered as hyperferritenemia..
\end{abstract}

Result: Nearly two-thirds of the women were in their $2^{\text {nd }}$ decades of life belonged to lower socioeconomic class. The body mass index was also fairly comparable between the groups with most women having normal BMI. No significant difference was observed between the groups with respect to obstetric variables as well. Level of haemoglobin and hematocrit were also identically distributed between groups. The result showed that a significantly higher proportion (35.5\%) preeclamptic women had elevated serum ferritin (>100 $\mu \mathrm{g} / \mathrm{L})$ as opposed to $10.3 \%$ of the control group $(p=0.021)$. The risk of developing raised serum ferritin in women with preeclampsia was estimated to be 4 -fold $(95 \% \mathrm{CI}=1.2-19.4)$ higher than that in the normal pregnant women. Analyses also revealed that women with severe preeclampsia had a higher mean serum ferritin $(207.3 \pm 44.1$ $\mathrm{ng} / \mathrm{ml})$ than the women with mild preeclampsia $(41.7 \pm 2.7)$ and an even higher level compared with the normal pregnant women $(21.7 \pm 1.4 \mu \mathrm{g} / \mathrm{ml})(p=0.001)$. Similar result was observed in serum iron with greater the severity, higher is the level of serum iron $(p=0.067)$. Conversely, the serum total iron binding capacity (TIBC) was decreased with severity of preeclampsia $(p=0.058)$.

Conclusion: The study concluded that women with preeclamsia might be associated with higher serum ferritin, higher serum iron and lower serum TIBC although it is not known whether the rise in serum ferritin and serum iron precedes or contributes to the clinical manifestations of preeclampsia.

Key words: Pregnant women, preclampsia, serum ferritin, serum iron and total iron binding capacity (TIBC) etc.

\section{INTRODUCTION:}

Preeclamsia (PE) is a multisystem disorder of unknown etilogy characterized by development of hypertension (HTN) with proteinuria after the $20^{\text {th }}$ weeks of pregnancy in a previously normotensive and non proteinuric women. ${ }^{1}$ It is the leading cause of maternal and perinatal morbidity and mortality. ${ }^{2}$ About $3-5 \%$ of the pregnancies in general are complicated with this syndrome ${ }^{3}$ and about $18 \%$ of pregnant women die of this problem. ${ }^{4}$ Other major

\footnotetext{
Author's information:

${ }^{1}$ Dr. Lipika Ghosh, MBBS, MS (Obstetrics \& Gynaecology), Assistant Professor, Colonel Malek Medical College, Manikganj

${ }^{3}$ Dr. Rowshan Afrooz, MBBS, MS (Obstetrics \& Gynaecology), Assistant Professor, Obstetrics \& Gynaecology, Nightingle Medical College, Dhaka

${ }_{2}^{2}$ Prof. Saleha Begum Chowdhury, MBBS, FCPS, Former Head of the Department, Obstetrics \& Gynaecology, BSMMU.

${ }^{4}$ Dr. Osman Gani, MBBS, DGO, MCPS (Obstetrics \& Gynaecology) Assistant Professor, Colonel Malek Medical College, Manikganj

${ }^{5}$ Dr. Rokhshana Khatun, MBBS, FCPS (Obstetrics \& Gynaecology) Assistant Professor, Colonel Malek Medical College, Manikganj

Correspondence: Dr. Lipika Ghosh, Phone: +880 1715-029206, E-mail:arabinda@amber.com.bd
} 
complications of preeclampsia are premature delivery and need for NICU utilization with its inherent problems. About $10 \%$ of women with preeclampsia/eclampsia develop HELLP Syndrome. ${ }^{5}$ The disease may be mild and inconsequential or may be severe enough to cause death or significant maternal morbidity from stroke, seizures, cerebral oedema, hepatic failure, renal failure, HELLP syndrome (haemolysis, elevated liver enzymes and low platelet count), disseminated intravascular coagulation (DIC), abruptio placentae. Foetal \& neonatal consequences include intrauterine growth retardation (IUGR), still birth \& severe prematurity due to premature termination of pregnancy for maternal indication. ${ }^{6}$

Despite many active researches for years, the exact aetiology of this potentially fatal disorder remains unknown. ${ }^{7} A$ number of theories have been put forward where different biochemical markers have been implicated in the causal association of preeclampsia. Iron parameters, among others, are also included in the causal association of preeclampsia. The increased level of serum ferritin in the second trimester of pregnancy is considered to be associated with the development of preeclampsia. A high level of ferritin has been associated with a variety of acute phase reaction including inflammatory condition. Several previous studies showed an association between elevated serum ferritin concentration \& pregnancy complications. ${ }^{8}$

Ferritin is a major iron storage protein found not only in spleen, liver and bone marrow, but also in mucosal cells of small intestine, in placenta, kidney, testes, skeletal muscle and in plasma. ${ }^{9}$ In pregnancy, serum ferritin concentration gets its maximum level early in the second trimester and then goes down with advancing gestation. ${ }^{10}$ Serum ferritin was found to be the best sensitive marker of the iron status parameters in preeclampsia and the result may support the role of iron as a catalyzer of oxidative stress and lipid peroxidation in the pathophysiology of preeclampsia. ${ }^{11}$ Studies in this regard suggest that serum iron, ferritin and transferrrin saturation rates are commendably higher in preeclampsia and TIBC level is lower than normal pregnant women. ${ }^{12,13}$
The probable role of serum iron, ferritin and TIBC in the development of preeclampsia, therefore, needs to be investigated. Evaluation of serum iron, ferritin and TIBC can be helpful in the identification of pregnant women at high risk for developing preeclampsia as well as diagnosis of preeclampsia before obvious clinical findings will be presented. The present study was, therefore, intended to find the association of serum iron parameters (serum iron, ferritin and TIBC) with preeclampsia \& also to see whether severity of preeclampsia increases with the increase in the levels of serum iron and ferritin.

\section{METHODS:}

This case-control study was conducted over a period of 12 months from July 2012 to June 2013 in the Department of Obstetrics \& Gynaecology, $\mathrm{DMCH}$, Dhaka. Pregnant women with and without preeclampsia who were hospitalized in the Department of Obstetrics \& Gynaecology of DMCH were the study population. Pregnant women with preeclampsia were considered as case, while the pregnant women without preeclampsia was included as control. Women, ranging between 20-35 years, having gestational age between 28 to 40 weeks and provided verbal/written consent to participate in the study were included.

Data were processed and analyzed using software SPSS (Statistical Package for Social Sciences) version 12.0. The test statistics used to analyse the data were descriptive statistics, Chi-square or Fisher's Exact Probability Test (for comparison of data presented on categorical scale) and Unpaired t-Test (for comparison of data presented on continuous scale). The risks of developing hyperferritenemia \& elevated iron and decreased TIBC in preeclamptics were calculated using Odds Ratio with $95 \%$ CI of Odds Ratio. For any analytical tests, the level of significance was set at 0.05 and $p$-value $<0.05$ was considered as significant.

\section{RESULTS:}

The women (in both case and control groups) were predominantly in their $3^{\text {rd }}$ decade of life (20-30 years) $(64.5 \%$ in the case group and $62.1 \%$ in the 
control group) with mean ages of the case and control groups being $26.5 \neq 5.9$ and $28.5 \neq 7.4$ years respectively $(p=0.259)$. The cases and controls were almost similar in terms of parity, gravida, gestational age and status of antenatal care (ANC) received during pregnancy ( $p>0.05$ in each case) (Table-I). About $55 \%$ of the preeclamptic patients had moderate oedema followed by $25.8 \%$ severe oedema and $19.4 \%$ mild oedema. The mean systolic and diastolic blood pressures at entry and 6 hours apart are shown in table II. Of the 31 cases, $10 \%$ had mild proteinuria $(1+), 42 \%$ had moderate proteinuria $(2+)$ and the rest $48 \%$ had severe proteinuria $(3+)$ (Table II). Table III illustrates the distribution of hematological parameters between case and control groups. The serum ferretin in the case group was observed to be staggeringly elevated and total iron binding capacity (TIBC) was significantly decreased compared to those in the control group ( $p=0.007 \& p<0.001$ respectively). The level of serum iron was also much higher in the former group compared to that in their control counterpart $(p=0.055)$. There was no significant difference between the study groups with respect to the level of haemoglobin ( $p=0.453$ ).

Over one-third (35.5\%) of the case group exhibited raised serum ferritin $(>100 \mu \mathrm{g} / \mathrm{L})$ as opposed to $10.3 \%$ of the control group $(p=0.021)$. The likelihood of having elevated serum ferritin in women with preeclampsia was estimated to be $>$ 4-fold ( $95 \% \mathrm{CI}=1.2-19.4$ ) higher than that in the normal pregnant women (Table IV). Table $\mathrm{V}$ illustrates that mean serum ferritin level of severe preeclampsia patients was $116.5 \mu \mathrm{g} / \mathrm{L}$, that of mild preeclampsia group was $96.7 \mu \mathrm{g} / \mathrm{L}$ and that of normal pregnant women was $73.7 \mu \mathrm{g} / \mathrm{L}$ indicating that greater the severity of preeclampsia the higher is the level of serum ferritin $(p<0.001)$. The level of serum iron was also higher in severe eclampsia and gradually decreased to mild preclampsia \& normal pregnant women $(p=0.067)$. The serum total iron binding capacity (TIBC), on the other hand, was gradually decreased with the severity of preeclampsia $(p=0.058)$. Perinatal outcome demonstrates that about $10 \%$ of the babies in case group were stillborn as opposed to none in the control group ( $p=0.131)$. Half of the babies born to mothers of the former group had IUGR, while only $10.3 \%$ of the babies in the latter group had the same consequence $(p=0.001)$. The incidence of birth asphyxia at 1 minute of birth was significantly higher in the case group (21.4\%) than that in the control group $(6.8 \%)(p=0.016)$. The need for resuscitation was much higher in case group (50\%) than that in the control group $(6.8 \%)$ $(p=0.018)$. Two $(7.1 \%)$ babies died within 7 days of birth. The risks of having IUGR, low birth weight, birth asphyxia and need for resuscitation in preeclamptic mothers were $8.6(95 \% \mathrm{CI}=2.1$ $35.3), 7.5(95 \% \mathrm{CI}=1.8-30.6), 2.1(95 \% \mathrm{CI}=$ $1.6-2.9)$ and $3.7(95 \% \mathrm{CI}=0.7-20.1)$ times greater respectively than those in the control group (Table VI).

\begin{tabular}{|c|c|c|c|}
\hline \multirow{2}{*}{$\begin{array}{l}\text { Age \& obstetric } \\
\text { characteristics }\end{array}$} & \multicolumn{2}{|c|}{ Group } & \multirow{2}{*}{$p$-value } \\
\hline & $\begin{array}{c}\text { Case } \\
(\mathrm{n}=31)\end{array}$ & $\begin{array}{l}\text { Control } \\
(n=29)\end{array}$ & \\
\hline \multicolumn{4}{|l|}{ Age (yrs)* } \\
\hline$<20$ & $6(19.4)$ & $3(10.3)$ & \\
\hline $20-30$ & $20(64.5)$ & $18(62.1)$ & \\
\hline$>30$ & $5(16.1)$ & $8(27.6)$ & \\
\hline Mean \pm SD $^{\#}$ & $26.5 \pm 5.9$ & $28.5 \pm 7.4$ & 0.259 \\
\hline \multicolumn{4}{|l|}{ Parity* } \\
\hline Nulipara & $20(64.5)$ & $19(65.5)$ & \\
\hline Primipara & $5(16.1)$ & $6(20.7)$ & 0.798 \\
\hline Multipara & $6(19.4)$ & $4(13.6)$ & \\
\hline \multicolumn{4}{|l|}{ Gravida* } \\
\hline Primigravida & 19(61.3) & $20(69.0)$ & 0.533 \\
\hline Multigravida & $18(38.7)$ & $9(31.0)$ & \\
\hline \multicolumn{4}{|c|}{ Gestational age (weeks)* } \\
\hline$<37$ (preterm) & $14(45.2)$ & $9(31.0)$ & 0.261 \\
\hline$\geq 37$ (term) & $17(54.8)$ & $20(69.0)$ & \\
\hline \multicolumn{4}{|l|}{ ANC* } \\
\hline Regular & $13(41.9)$ & $15(55.2)$ & \\
\hline Irregular & $12(38.7)$ & $10(34.5)$ & 0.490 \\
\hline Not Done & $6(19.4)$ & $3(10.3)$ & \\
\hline
\end{tabular}

*Figures in the parentheses indicate correspondingpercentage; $\chi^{2}$ Test was done to analyse the data.

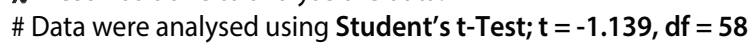




\begin{tabular}{|c|c|c|c|}
\hline $\begin{array}{l}\text { Clinical } \\
\text { variables }\end{array}$ & Frequency & Percentage & $\begin{array}{c}\text { Mean } \pm \text { SEM } \\
\text { (range) }\end{array}$ \\
\hline \multicolumn{4}{|l|}{ Oedema** } \\
\hline Nil & 00 & 0.0 & --- \\
\hline Mild & 06 & 19.4 & --- \\
\hline Moderate & 17 & 54.8 & --- \\
\hline Severe & 08 & 25.8 & --- \\
\hline \multicolumn{4}{|l|}{ Blood pressure } \\
\hline Systolic BP on admission & --- & --- & $163.2 \pm 20.1$ \\
\hline Diastolic BP on admission & $n \quad---$ & --- & $109.2 \pm 10.9$ \\
\hline Systolic BP 6 hours apart & -- & --- & $146.2 \pm 17.6$ \\
\hline Diastolic BP 6 hours apart & t $\quad---$ & --- & $102.3 \pm 10.1$ \\
\hline \multicolumn{4}{|l|}{ Grading of proteinuria } \\
\hline Mild & 3 & 10.0 & --- \\
\hline Moderate & 13 & 42.0 & --- \\
\hline Severe & 15 & 48.0 & \\
\hline
\end{tabular}

*Figures in the parentheses indicate correspondingpercentage; ${ }^{* *}$ Chi-square $\left(\chi^{2}\right)$ Test was done to analyse the data; $\chi^{2}=60.000, \mathrm{df}=3$ \#Data were analysed using Student's t-Test and were presented as mean \pm SD.

\begin{tabular}{|c|c|c|c|}
\hline \multirow{2}{*}{$\begin{array}{l}\text { Hematological } \\
\text { parameters* }\end{array}$} & \multicolumn{2}{|c|}{ Group } & \multirow[b]{2}{*}{$\mathrm{p}$-value } \\
\hline & $\begin{array}{c}\text { Case } \\
(n=31)\end{array}$ & $\begin{array}{l}\text { Control } \\
(n=29)\end{array}$ & \\
\hline Serum iron $(\mu \mathrm{g} / \mathrm{dl})$ & $104.4 \pm 13.7$ & $73.2 \pm 7.4$ & 0.055 \\
\hline Serum ferritin $(\mu g / L)$ & $114.3 \pm 30.6$ & $24.4 \pm 3.5$ & 0.007 \\
\hline $\begin{array}{l}\text { Total iron-binding } \\
\text { capacity }(\mu \mathrm{g} / \mathrm{dl})\end{array}$ & $384.9 \pm 61.4$ & $529.0 \pm 29.6$ & $<0.001$ \\
\hline Haemoglobin (g/dl) & $10.8 \pm 1.5$ & $11.1 \pm 1.0$ & 0.453 \\
\hline
\end{tabular}

*Data were analysed using Student's t-Test \& were presented as mean \pm SD.

TABLE IV. Association between serum ferritin and preeclampsia

\begin{tabular}{|c|c|c|c|c|}
\hline \multirow{2}{*}{$\begin{array}{l}\text { Serum level } \\
\text { of ferritin }(\mu \mathrm{g} / \mathrm{L})^{*}\end{array}$} & \multicolumn{2}{|c|}{ Group } & \multirow[b]{2}{*}{ OR $(95 \% \mathrm{Cl})$} & \multirow[b]{2}{*}{$p$-value } \\
\hline & $\begin{array}{c}\text { Case } \\
(n=31)\end{array}$ & $\begin{array}{l}\text { Control } \\
(n=29)\end{array}$ & & \\
\hline$>100$ & $11(35.5)$ & $3(10.3)$ & \multirow[t]{2}{*}{$4.7(1.2-19.4)$} & \multirow[t]{2}{*}{0.021} \\
\hline$\leq 100$ & $20(64.5)$ & 26(89.7) & & \\
\hline
\end{tabular}

Figures in the parentheses denote corresponding percentage; * Data were analysed using $\chi^{2}$ Test.

\begin{tabular}{|c|c|c|c|c|}
\hline \multirow{2}{*}{$\begin{array}{l}\text { Hematological } \\
\text { parameters }\end{array}$} & \multicolumn{3}{|c|}{ Group } & \multirow[b]{2}{*}{ p-value } \\
\hline & $\begin{array}{c}\text { Severe } \\
\text { preeclampsia } \\
(n=12)\end{array}$ & $\begin{array}{c}\text { Mild } \\
\text { preeclampsia } \\
(\mathrm{n}=19)\end{array}$ & $\begin{array}{l}\text { Control } \\
(n=29)\end{array}$ & \\
\hline Serum iron ( $\mu \mathrm{g} / \mathrm{dl})$ & $116.5 \pm 26.2$ & $96.7 \pm 15.5$ & $73.1 \pm 7.4$ & 0.067 \\
\hline Serum ferritin $(\mu \mathrm{g} / \mathrm{L})$ & $121.8 \pm 46.5$ & $102.5 \pm 31.2$ & $24.4 \pm 3.5$ & 0.001 \\
\hline $\mathrm{TIBC}(\mu \mathrm{g} / \mathrm{dl})$ & $380.5 \pm 20.1$ & $391.8 \pm 28.9$ & $529.0 \pm 29.6$ & 0.058 \\
\hline
\end{tabular}

\#Data were analysed using ANOVA statistics and were presented as mean \pm SD.
TABLE VI. Association between preeclampsia and perinatal outcome

\begin{tabular}{|c|c|c|c|c|}
\hline \multirow{2}{*}{$\begin{array}{l}\text { Perinatal } \\
\text { outcome }\end{array}$} & \multicolumn{2}{|c|}{ Group } & \multirow[b]{2}{*}{ OR $(95 \% \mathrm{Cl})$} & \multirow[b]{2}{*}{$\mathrm{p}$-value } \\
\hline & $\begin{array}{c}\text { Case } \\
(n=31)\end{array}$ & $\begin{array}{l}\text { Control } \\
(n=29)\end{array}$ & & \\
\hline Still-born & $3(9.7)$ & $0(0.0)$ & Not computed & 0.131 \\
\hline IUGR & $14(50.0)$ & $3(10.3)$ & $8.6(2.1-35.3)$ & 0.001 \\
\hline Birth weight $<2.5 \mathrm{~kg}$ & 13(46.4) & $3(10.3)$ & $7.5(1.8-30.6)$ & 0.002 \\
\hline APGAR $<7$ at birth & $6(21.4)$ & $2(6.8)$ & $2.1(1.6-2.9)$ & 0.016 \\
\hline APGAR $<7$ at 5 minute & $4(14.8)$ & $3(10.3)$ & Not computed & 0.459 \\
\hline Resuscitation needed & $14(50.0)$ & $2(6.8)$ & $3.7(0.7-20.1)$ & 0.018 \\
\hline Death within 7 days & $2(7.1)$ & $0(0.0)$ & Not computed & 0.237 \\
\hline
\end{tabular}

Figures in the parentheses denote corresponding percentage; \# Data were analysed using $\chi^{2}$ Test.

\section{DISCUSSION:}

In the present case-control study majority of the women was in their $3^{\text {rd }}$ decade of life. No significant difference was observed between the groups in terms of obstetric characteristics as well. The study subjects were predominantly preterm with slightly higher numbers of multigravida in the case group. Level of haemoglobin and iron parameters were also identically distributed between groups.

In the present study a significantly higher proportion $(35.5 \%)$ of preeclamptic women exhibited elevated serum ferritin ( $>100 \mathrm{ng} / \mathrm{ml}$ ) as opposed to $10.3 \%$ of the control group $(p=0.021)$. The risk of developing elevated serum ferritin in women with preeclampsia was estimated to be 4-fold ( $95 \%$ CI $=1.2-19.4$ ) higher than that in the normal pregnant women. As all the demographic and obstetric characteristics were almost matched statistically, the significantly higher level of serum ferritin in the case group compared to the control group could be attributed to preeclampsia. This evidence is further supported by the data that women with severe preeclampsia had a higher mean serum ferritin $(207.3 \pm 44.1 \mathrm{ng} / \mathrm{ml})$ than the women with mild preeclampsia $(41.7 \pm 2.7)$ and an even higher level compared with the normal pregnant women $(21.7 \pm 1.4 \mathrm{ng} / \mathrm{ml})(p=0.001)$. Similar trend was observed in serum iron with greater the severity, higher is the level of serum iron $(p=0.067)$. Conversely, the serum total iron binding capacity (TIBC) is decreased with severity of preeclampsia $(p=0.058)$. 
Several other studies reported similar findings, where serum iron \& ferritin and transferrrin saturation rates are remarkably higher in preeclampsia and TIBC level is lower than normal subjects. ${ }^{12-14}$ In a study it was evident that mean serum iron concentration was higher $(135 \mu \mathrm{g} / \mathrm{dl})$ in patients with preeclampsia compared to that in normotensive parturients $(62 \mu \mathrm{g} / \mathrm{dl})$ and chronic hypertensive parturient $(72 \mu \mathrm{g} / \mathrm{dl})$. Mean iron for patients with eclampsia was $203 \mu \mathrm{g} / \mathrm{dl}$ and that for patients with severe preeclampsia was $137 \mu \mathrm{g} / \mathrm{dl}$. When hepatocellular injury occurred, mean ferritin increased to $421 \mathrm{ng} / \mathrm{ml}$. ${ }^{15}$ Taheripanah \& Farkush ${ }^{16}$ demonstrated that ferritin level in preeclampsia was 3.6 times higher to that in normal pregnant women which is quite consistent with the findings of the present study. Lower ferritin level during 28-30 weeks of pregnancy would be associated with lower incidence of preeclampsia. ${ }^{17}$

Normally both serum iron and ferritn show a decrease with advancing gestation due to hemodilution and depletion of iron stores to meet the increasing needs of the growing conceptus. ${ }^{18}$ In developing countries, the depletion is of much higher order due to a high prevalence of iron deficiency anemia, where, serum ferritin concentration gets its maximum level at 12-16 weeks of gestation and then falls with advancing gestation. ${ }^{10}$ Serum ferritin level changes during pregnancy with advancing gestation and reaches the minimum at the third trimester to 20 $\mathrm{ng} / \mathrm{ml} .^{19,20}$ The serum ferritin is the best sensitive marker of the iron status in preeclampsia and the result may support the role of iron as a catalyzer of oxidative stress and lipid peroxidation in pathophysiology of the disease. ${ }^{11}$

Hyperferritinemia in patients with preeclampsia appears to be attributable to the combined effects of increased ferritin synthesis and the release of intracellular ferritin from damaged cells. Hepatocellular, rather than placental, damage is the likely reason for the predominance of nonglycosylated ferritin in many women with preeclampsia. ${ }^{21}$ It would, therefore, seem reasonable that in the absence of evidence of iron deficiency, it is better not to give iron supplements to pregnant women. ${ }^{22}$ The increases in serum iron and ferritin are striking and may even have the potential to be used diagnostically to warn of impending preeclampsia.

\section{CONCLUSION:}

From the findings of the study it can be concluded that women with preeclamsia might be associated with higher serum ferritin, higher serum iron with lower TIBC. The study data also suggest that the greater the severity of preeclampsia, the higher is the level of serum ferritin and serum iron and lower is the TIBC. However, from the data it cannot be conclusively stated whether the rise in serum ferritin and serum iron precedes or contributes to the clinical manifestations of preeclampsia. Whatever it is, all pregnant women should be screened for serum ferritin in their second trimesters in order to issue precautionary measures against the potential development of preeclampsia and its possible maternal and perinatal consequences.

\section{REFERENCES:}

1. Konar H. Hypertensive disorders in pregnancy, D.C. Dutta's text book of Obstetrics. 2015;8:255.

2. Walker JJ. Pre-eclampsia. Lancet 2000;356:1260-65.

3. Ventura SJ, Martin JA, Curtin SC, Mathews TJ, Park MM. Births: Final Data for 1998. Natl Vital Stat Rep 2000; 48(3): 1-100.

4. Berg CJ, Atrash HK, Koonin LM, Tucker M. Pregnancy related mortality in the United States (1987-1990). Obstet \& Gynaecol 1996:161.

5. Cunninhham FG, Leveno KJ, Bloom SL, Hauth JC, Gilstrap L, Wenstrom KD. Williums Obstetrics, $22^{\text {th }}$ edition', Mc Graw Hill, Medical Publishing Division. 2005.

6. Dorothy JV, Rina JP, Aliyu UE, George SM, Michael JC, Robert HG. High-density lipoprotein and homocysteine levels correlate inversely in preeclamptic women in northern Nigeria. Acta Obstet Gynaecol Scand 2004;83: 546-52.

7. Mandal NG, Surapaneni S. Regional anaesthesia in pre-eclampsia: advantages and disadvantages. Drugs 2004;64(3):223-36.

8. Greenhagen JB, Van Wagoner J, Dudley D, Hunter C, Mitchell M, Logsdon V, Casal D, Varner M. Value of fetalfibronectin as a predictor of preterm delivery for a 
low-risk population. Am J Obstet Gynecol 1996;175(4 Pt 1):1054-56.

9. Circhton RR. The biochemistry of ferritin. $\mathrm{Br} \mathrm{J}$ haematol $1973 ; 26: 677$.

10. Milman, $\mathrm{N}, \mathrm{Agger}, \mathrm{AO} \&$ Nielsen, OJ. Iron status markers and serum erythropoietin in 120 mothers and newborn infants. Acta Obstet Gynecol Scand 1994;73:200.

11. Kwon, I, Kwon, JY \& Lee, JK. Maternal serum iron related parameters in severe preeclampsia. Korean J Obstet Gynecol 2007;50:1064.

12. Vitoratos $N$, Salamalekis $E$, Dalmaga NJ, Kassanos $D$, Creatsas G. Defective antioxidant mechanisms via changes in serum ceruloplasmin and total iron binding capacity of serum in women with pre-eclampsia. Eur J Obstet Gynecol Reprod Biol 1999;8(41):63-7.

13. Adam B, Malatyalioglu E, Alvur M, Talu C. Magnesium, zinc and iron levels in pre-eclampsia. J Martern Fetal Med 2001;104:246-50.

14. Hubel CA. Dyslipidemia, iron, and oxidative stress in preeclampsia: assessment of meternal \& fetoplacental interactions. Semin Repord Endocrinol 1998;16(1): 75-92.

15. Entman, SS, Richardson, LD \&Killam, PP. Altered ferrokinetics in toxemia of pregnancy: a possible indicator of decreased red cell survival. Clin Exp Hypertens 1983;2:171.
16. Taheripanah R, Farkush PB. Relation between serum ferritin and iron parameters with preeclampsia. J Family Reprod Health 2007;1(2):87-91.

17. Lao TT, Tam KF, Chan LY. Third trimester iron status and pregnancy outcome in non-anemic women: pregnancy unfavourably affected by maternal iron excess. Hum Reprod 2000;168:1843-8.

18. Kaneshige E. Serum ferritin as an assessment of iron stores and other hematological parameters during pregnancy. Obstet Gynecol 1981;57:238-42.

19. Cavill I. Iron metabolism and erythropoiesis in chronic disease states. Erythropoiesis New Dimens Treat anemia 1996;7:98-101.

20. Halliwel B, Gutteriadge JM. Role of free radicals and caralytic metal icons in human disease:an overview. Methods Enzymol 1990;186:1-85.

21. Carl, A, Hubel, A \& Lisa, M. Nonglycosylated ferritin predominates in the circulation of women with preeclampsia but not Intrauterine growth restriction. American Association for Clinical Chemistry 2004;50: 948.

22. Rayman, MP, Barlis, J, Evans, RW. Abnormal iron parameters in the pregnancy syndrome preeclampsia. Am J Obstet Gynecol 2002;187:412. 